\title{
Indeterminate single bone lesion on multimodality imaging of prostate cancer
}

\author{
Angela Mujukian, Michael Kay
}

Division of Oncological PET/ CT, Department of Radiology and Nuclear Medicine, Poole Hospital NHS Foundation Trust, Poole, UK

\section{Correspondence to}

Dr Angela Mujukian, amujukian@gmail.com

Accepted 15 December 2018

\section{DESCRIPTION}

A 70-year-old asymptomatic man presented to hospital in 2017 for routine surveillance of previously stable prostate cancer being managed with a 'watch and wait' approach. The medical history was unremarkable, performance status 0 . Initial diagnosis was 8 years prior with T2aN0M0 Gleason 3+3, Prostate specific antigen (PSA) $7.60 \mathrm{ng} / \mathrm{mL}$.

On active surveillance, his PSA had slightly risen to $8.30 \mathrm{ng} / \mathrm{mL}$.

Imaging restaging with $99 \mathrm{mTechnetium} \mathrm{meth-}$ ylene hydroxydiphosphonate bone scintigraphy $\left({ }^{99} \mathrm{mTc}-\mathrm{HDP}\right)$ revealed a solitary bone abnormality in the proximal right tibia (figure 1), and pelvic MRI demonstrating localised pelvic nodal disease, T3bN1. Template biopsy confirmed prostate adenocarcinoma, now graded as Gleason $4+3$.

The multidisciplinary cancer meeting requested an ${ }^{18} \mathrm{~F}$-choline Positron emission tomographycomputed tomography (PET/CT) (figure 2) to further assess. The patient would be eligible for radical prostate and nodal radiotherapy if free of metastatic bone disease. ${ }^{18} \mathrm{~F}$-choline PET/CT confirmed avid tracer uptake in the left pelvic nodes (figure 3). The left tibial lesion showed abnormal choline uptake with a corresponding morphological abnormality on CT. This was a single site of abnormal bone uptake. This was felt to be an atypical site of bony metastatic disease. Further imaging with plain radiography and MRI did not clarify the nature of the lesion. Biopsy of the abnormal tibial lesion was performed. This remained an indeterminate lesion which was MNF-116 cytokeratin negative, effectively excluding metastatic disease. ${ }^{1}$ With metastatic disease excluded, a pragmatic approach was taken to treat the prostatic primary and local nodal disease with radical radiotherapy, ipso facto, the tibial lesion was considered an incidental finding of no clinical relevance.

The patient received 74 Gy in $37 \mathrm{f}$ of pelvic nodal radiotherapy and responded well. In follow-up of 2018, PSA at 1 year dropped from a previous $8.30 \mathrm{ng} / \mathrm{mL}$ to $0.07 \mathrm{ng} / \mathrm{mL}$ following the radiotherapy to the prostate and pelvic nodes and maintenance by luteinizing hormone releasing hormone (LHRH) analogue.

While 99mTechnetium methylene di-phosphonate bone scintigraphy $\left({ }^{99} \mathrm{Tc}-\mathrm{MDP}-\mathrm{bone}\right.$ scan) remains the gold standard of staging for bony metastatic disease in prostate cancer, newer techniques such as MRI with whole body diffusion imaging and PET/CT using ${ }^{18} \mathrm{~F}$-choline

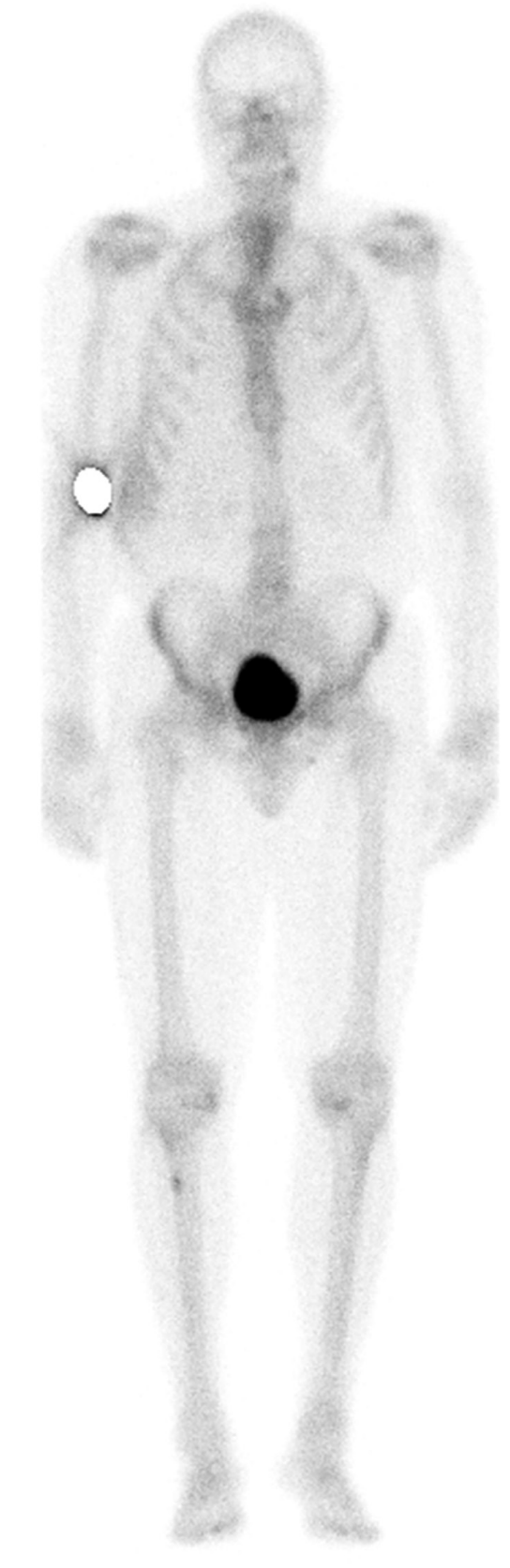

Figure 1 Anterior whole-body planar image of ${ }^{99} \mathrm{mTc}$ HDP bone scan showing increased uptake in the proximal right tibial cortex lesion.

are increasingly playing a part in multimodality imaging of prostate cancer however despite a high sensitivity are not completely specific to 


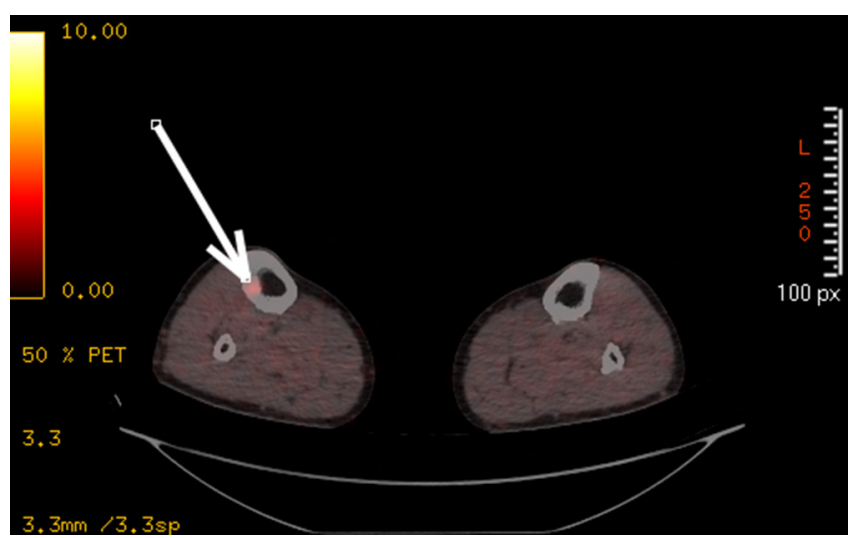

Figure 2 Axial fused ${ }^{18} \mathrm{~F}$-choline PET/CT, arrow showing an abnormally increased tracer uptake within the right tibial cortex lesion.

prostate cancer metastases. ${ }^{2}$ The sensitivity and specificity of ${ }^{18} \mathrm{~F}$-choline PET/CT increases with PSA and Gleason grade.

Choline is a precursor of the phospholipids in cell membranes via the Kennedy pathway. The increased cell membrane synthesis seen in prostate cancer (and other

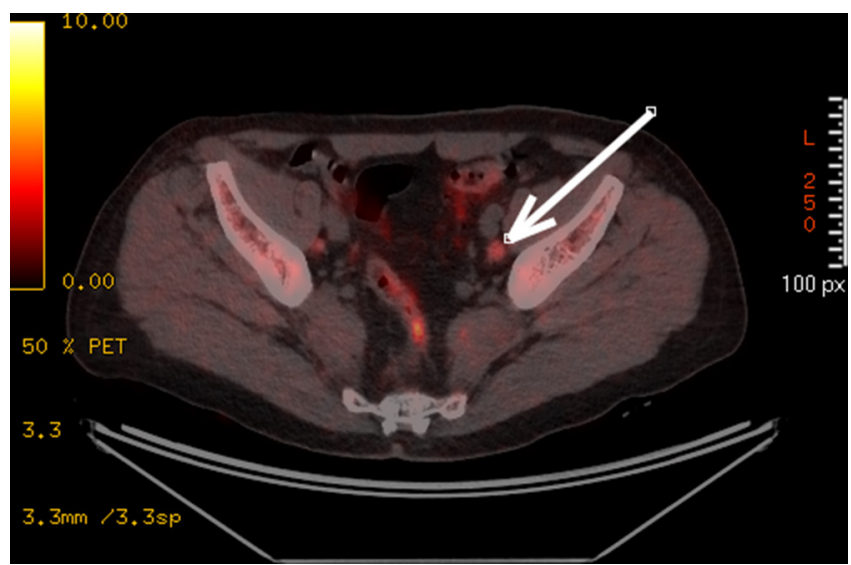

Figure 3 Axial fused ${ }^{18} \mathrm{~F}$-choline PET/CT, arrow showing an abnormally increased tracer uptake within an abnormal left external iliac node. malignant/inflammatory/infective processes) is the reason for the increased tracer uptake seen on PET/CT.

Newer PET/CT tracers such as ${ }^{18} \mathrm{~F}$-fluciclovine and 68-Gallium-prostate specific membrane antigen $\left({ }^{68} \mathrm{Ga}\right.$ PSMA) are increasingly finding a role in prostate cancer imaging. ${ }^{18}$ F-PSMA tracers are in clinical development which will provide the combination of high lesion sensitivity without the downside of a short half-life which limits ${ }^{68} \mathrm{Ga}$ PSMA distribution. ${ }^{3}$

\section{Learning points}

${ }^{18} \mathrm{~F}$-choline PET/CT may be used as a complementary imaging modality agent to ${ }^{99} \mathrm{Tc}-\mathrm{MDP}$-bone scintigraphy in cases of bone metastases in prostate cancer and can clarify indeterminate findings due to its advantage of being a hybrid $\mathrm{CT}$ and PET modality.

- ${ }^{18} \mathrm{~F}$-choline PET/CT is indicated to clarify staging on conventional imaging and to exclude metastases prior to localised prostate or prostate \pm local nodal treatment.

- No imaging biomarker is completely specific to prostate cancer cells so imaging information from complementary studies is required, with the use of lesion biopsy in indeterminate cases.

Contributors AM: conception, design, data aquisition, interpretation/analysis, original drafting, manuscript revisions, accountable for accuracy and integrity of work. MK: patient care, consent, conception, design, manuscript writing, manuscript revisions, final approval/accountable for all aspects of work.

Funding The authors have not declared a specific grant for this research from any funding agency in the public, commercial or not-for-profit sectors.

Competing interests None declared.

Patient consent Obtained.

\section{REFERENCES}

1 Quentmeier H, Osborn M, Reinhardt J, et al. Immunocytochemical analysis of cell lines derived from solid tumors. J Histochem Cytochem 2001;49:1369-78

2 Scarsbrook A, Barrington S. Evidence-Based Indications for the Use of PET/CT in the United Kingdom 2016. The Royal College of Radiologists and Royal College of Physicians 2016.

3 Bouchelouche K, Choyke PL, Capala J. Prostate specific membrane antigen- a target for imaging and therapy with radionuclides. Discov Med 2010:9:55-61.

Copyright 2018 BMJ Publishing Group. All rights reserved. For permission to reuse any of this content visit

https://www.bmi.com/company/products-services/rights-and-licensing/permissions/

BMJ Case Report Fellows may re-use this article for personal use and teaching without any further permission.

Become a Fellow of BMJ Case Reports today and you can:

- Submit as many cases as you like

- Enjoy fast sympathetic peer review and rapid publication of accepted articles

Access all the published articles

- Re-use any of the published material for personal use and teaching without further permission

For information on Institutional Fellowships contact consortiasales@bmjgroup.com

Visit casereports.bmj.com for more articles like this and to become a Fellow 